\title{
Effects of Exchange Rate Volatility on the Stock Market: A Case Study of South Africa
}

\author{
Courage Mlambo \\ PhD, University of Fort Hare \\ (Corresponding Author) Email: mlamboct@gmail.com \\ Andrew Maredza \\ Department of Economics, North West University \\ Email: Andrew.Maredza@nwu.ac.za \\ Kin Sibanda \\ PhD, University of Fort Hare \\ Email:keith08.kin@gmail.com
}

\section{Doi:10.5901/mjss.2013.v4n14p561}

\section{Abstract}

This study assessed the effects of currency volatility on the Johannesburg Stock Exchange. An evaluation of literature on exchange rate volatility and stock markets was conducted resulting into specification of an empirical model. The Generalised Autoregressive Conditional Heteroskedascity (1.1) (GARCH) model was used in establishing the relationship between exchange rate volatility and stock market performance. The study employed monthly South African data for the period 2000 2010. The data frequency selected ensured an adequate number of observations. A very weak relationship between currency volatility and the stock market was confirmed. The research finding is supported by previous studies. Prime overdraft rate and total mining production were found to have a negative impact on Market capitalisation. Surprisingly, US interest rates were found to have a positive impact on Market capitalisation. The study recommended that, since the South African stock market is not really exposed to the negative effects of currency volatility, government can use exchange rate as a policy tool to attract foreign portfolio investment. The weak relationship between currency volatility and the stock market suggests that the JSE can be marketed as a safe market for foreign investors. However, investors, bankers and portfolio managers still need to be vigilant in regard to the spillovers from the foreign exchange rate into the stock market. Although there is a weak relationship between rand volatility and the stock market in South Africa, this does not necessarily mean that investors and portfolio managers need not monitor the developments between these two variables.

Keywords: rand volatiltity, exchange rate fluction, flexible exchange rate, stock market, GARCH.

\section{Introduction}

The volatility of exchange rates is at the center of the debate on the performance of exchange rate regimes. This concern was reinforced by the fluctuations in exchange rates since the move to flexible exchange rate systems in 1973 (Omojimite and Akpokodje 2010). A major concern has the consequence of exchange rate volatility which is a prominent feature of flexible exchange rate systems. Exchange rate volatility has been a source of concern in many economies including South Africa. The rand has been the most volatile among emerging currencies over the past few years. South Africa's recent measures to reduce the rand's volatility haven't had a desired impact as the currency's fluctuation is fueled by global economic instability and capital inflows from developed countries (Davies, 2010). Over the past decade South Africa has experienced significant volatility. Pretorius and de Beer (2002) note that the "worrying volatility of the rand resulted in the appointment of the Myburgh Commission of inquiry into the depreciation of the rand. From January 1 , 1996 to May 29, 2002, the value of the rand depreciated from R3.64 per US\$ to R9.85, reaching an all-time low of R13.002 on December 20, 2001".

Over the years, the rand exchange rate has continued to display a relatively high degree of volatility in response to erratic changes in global risk aversion. The currency plunged to a two-year low of R8.49 in late September (2011) from around R6.80 at the start of August and has since rebounded to R7.89 (Mail and Guardian, 2011). Nedbank (2012) 
further maintains that the rand rose by 0, 4\% against the US dollar in May and June 2012 and later firmed against the US dollar by $0.7 \%$ in August and September 2012. All these statistics showed that the rand has been volatile and vulnerable to both local and international developments.

In the financial sector, South Africa is seen as having one of the best run emerging economies in the world, with efficiently managed world class companies. According to the United Nation Economic Commission for Africa (UNECA, 2008), the Johannesburg Stock Exchange (JSE) stands as an attractive vehicle for the infusion of foreign investments in Africa. The JSE (established in 1886) is the oldest stock exchange market in Africa. The UNECA (2008) maintains that the JSE, in its 120 years of existence, has developed into one of the biggest stock exchange in the world. African markets are usually characterized by low capitalization and are still regarded as infants in the world stock exchange. In contrast to this, the JSE has emerged as one of the best in the world. By March 2011, the JSE was ranked $20^{\text {th }}$ in the world and the value of market capitalization was 6,785.6 billion dollars up from 6,143.2 dollars the previous year (JSE, 2011).

However, the JSE has been affected by exchange rate movements in recent years. "In the early 2000s, the South African Reserve Bank (SARB) tightened its monetary policy in a bid to keep inflation within the target band of 3-6\%. Consequently, the SA rand appreciated significantly. However the strength of the rand led to a $10 \%$ decline in the JSE index in local currency terms and $24 \%$ increase in US dollar terms" (UNECA, 2008). High currency volatility makes it difficult for businesses to plan and budget. Currency risk presents a curious problem. On the one hand, currency movements will have a large impact on the rand value of cash flows from foreign projects. Further, to the extent that the project involves a mixture of local and international costs or revenues, currency changes will also alter the local currency cash flows (Stern and Chew, 2003). Benita and Lauterbach (2004) argue that currency volatility have costs that have negative effect on price stability and consequently on firm profitability. Currency volatility has implications for the financial system especially the stock market. Stock market plays a very crucial role in assessing economic conditions of any country through improved stock returns usually signified by higher profit to firms. Stock markets serve as channels through which funds can be exchanged between savers and spenders (investors) who will be in need of funds (Mishkin 2001). Fluctuations in the exchange rate can, therefore, affect the performance of the stock market as well as the financial sector.

\section{Literature Review}

This section uncovers whether or not existing theories and studies suggest that currency volatility has an impact on the stock market. There is no agreement on the existence of a relationship between stock prices and exchange rates.

\subsection{Theoretical literature}

This part explores the theoretical literature applicable to this study, with considerations being made to the Flow oriented model, Stock oriented model and the Arbitrage Pricing Theory.

\subsubsection{Flow oriented model}

The model maintains that a causal relationship runs from the exchange rate to the stock prices. In other words, exchange rate movements affect the stock prices. Exchange rate changes affect the competitiveness of firms through their impact on input and output prices (Joseph, 2002). When the exchange rate appreciates, exporters will be negatively affected. An appreciation of the currency will cause their goods and services to be dearer on the international market. This will cause their exports to decline, as they will be seen as expensive by buyers on the international market. This will result in them losing competitiveness internationally. Consequently, their profits will decline and if profits decrease the firms will lose competitiveness on the domestic stock market. Their attractiveness on the domestic stock market will decrease and this will result in their stock prices decreasing in value. Resultantly, a negative relation between domestic currency and stock price can be confirmed.

\subsubsection{Stock oriented model}

Pilbeam (1992:159) points out an obvious problem with the flow oriented model as being that they have nothing to say about international capital movements, although it is known that international capital movements are very large and 
dominate the foreign currency market. Stock oriented models put much stress on the role of the financial (formerly capital) account in the exchange rates determination. Adjasi and Biekpe (2007) held that in the "stock oriented model, the exchange rate equates demand and supply for assets (bonds and stocks)". Therefore, expectations of relative currency movements have a significant impact on price movements of financially held assets. In other words, currency fluctuations may influence stock price movements.

\subsubsection{Arbitrage Pricing Theory (APT)}

Chen et al. (1986) in Iqbal and Haider (2005) argue that risk factors (in the APT) arise from changes in some fundamental economic and financial variables such as interest rates, inflation, real business activity, exchange rate among other variables. Rashid and Karachi (2007) held that according to the Arbitrage theory, a rise in real interest rate reduces the present value of a firm's future cash flows and causes stock prices to fall. But at the same time, a higher interest rate stimulates the capital inflow, and therefore exchange rate falls. So the real interest rate disturbance may be a factor of a positive relationship between the average level of stock prices and exchange rates. In this regard, the model assumes that macroeconomic variables such as exchange rate can have an effect on the stock market.

\subsection{Empirical literature}

The behavior of volatility of stock market has been extensively studied using the ARCH-GARCH framework pioneered by Engel (1982) and further developed by Bollerslev (1986), and others. However, the results of some of these studies are inconclusive. Adjasi and Biekpe (2005) investigated the relationship between stock prices and exchange rate movement in Ghana, South Africa, Egypt, Kenya, Mauritius and Nigeria. A VAR model was used to examine the relationship between exchange rates and stock prices. Findings from their study indicated that there was no long-run stable relationship between stock market prices and exchange rates for Egypt, Ghana, Kenya, Mauritius, Nigeria and South Africa. In another study, Pilinkus and Boguslauskas (2009) used the impulse response function to test the existence of the short-run relationship between stock market prices and macroeconomic variables. Their study concluded that unemployment rate, exchange rate, and short-term interest rates negatively influence stock market prices.

Muhammad and Rasheed (2011) conducted a study on the relationship between stock prices and exchange rates in four South Asian countries; Pakistan, India, Bangladesh and Sri- Lanka, for the period January 1994 to December 2000. The study employed cointegration, vector error correction modeling technique and standard Granger causality tests to examine the long-run and short-run association between stock prices and exchange rates. Results of the study showed no short-run association between the variables for all four countries. There was no long-run relationship between stock prices and exchange rates for Pakistan and India as well. However, for Bangladesh and Sri- Lanka, there appeared to be a bi-directional causality between these two financial variables.

Sekmen (2011) examined the effects of exchange rate volatility, using the squared residuals from the autoregressive moving average (ARMA) models, on stock returns for the U.S. for the period 1980 to 2008. The study found that exchange rate volatility negatively affected U.S. stock returns since the availability of hedging instruments could not lessen the negative effect of exchange rate volatility on trade volume. In another study, Olugbenga (2012) examined the long-run and short-run effects of exchange rate on stock market development in Nigeria over 1985:12009:4 using the Johansen cointegration tests. Results showed a significant positive stock market performance to exchange rate in the short-run and a significant negative stock market performance to exchange rate in the long-run.

Empirical literature investigated by the study showed that that there are mixed views on the link between the two variables. Interesting to note is that some studies like that of Alam and Tafiques (2007) admit that there is need for continuous research in the area of exchange rates and stock markets. Moreover, studies in other countries also provided room for further research. Morales (2008) admitted that further research along these lines ${ }^{1}$ is required in order to establish more comprehensively the true nature of spillovers from exchange rates to equity markets.

\section{An Overview of Currency Volatility and Developments on the JSE}

The aim of this chapter is to present an overview of the exchange rate movements and developments on the JSE over the period 2000 to 2010. An analysis of the volatility of the rand shall be done first followed by an analysis of the

\footnotetext{
${ }^{1}$ Exchange rate and stock market
} 
developments on the JSE.

\subsection{An overview of the volatility of the rand}

Currency volatility was identified by the South African authorities as one of the constraints on growth in Accelerated and Shared Growth Initiative for South Africa (ASGISA) in 2006 (OECD, 2010). The sources of rand instability or volatility are exogenous. In effect, fundamental shifts in the dynamics of the global capital market, together with marginally high domestic interest rates, lead to sustained strength and volatility of the currency (Hale and Hughes, 2011:136). The instability or volatility of the rand has, also, been caused by large fluctuations in financial flows and this has made the achievement of the stability of the rand to be nearly impossible. Since the adoption of a floating exchange rate regime together with the inflation-targeting monetary policy framework, substantial swings have occurred in the exchange rate of the rand. From the year 2000 when the inflation targeting-flexible exchange regime was adopted, the rand has undergone an era of excessive volatility. This is reflected in Figure 1.

Figure 1: Rand/US Exchange Rate fluctuations

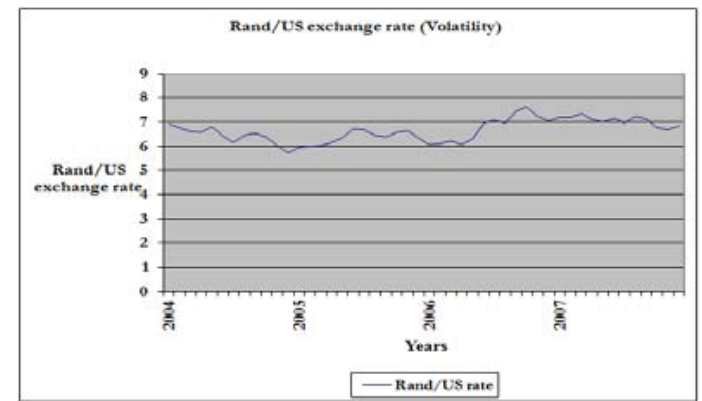

Source: Data compiled from SARB, (2012)

From figure 1 it can be observed that although the rand could not depreciate and appreciate with high margins between 2004 and 2007, it was not stable hence we can conclude that it was volatile. The rand fluctuated considerably and it was never stable enough for volatility to be ruled out. The fact that it fluctuated in these years makes the rand to be deemed volatile between the 2004 and 2007 period. The volatility continued in the following years that are 2008, 2009 and 2010. This is shown in figure 2.

Figure 2: Rand/US Exchange Rate fluctuations (2008-2010)

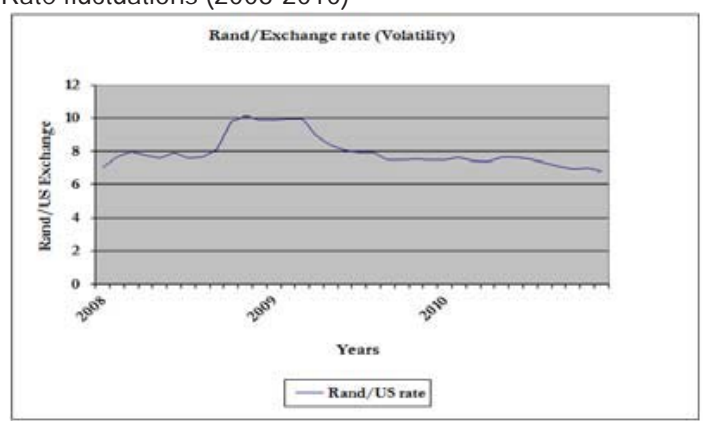

Source: Data compiled from SARB, (2012)

Figure 2 shows that the period between 2008 and 2010 was marked by rand exchange rate volatility. Significant levels of volatility can be observed especially in the first two years - that is in the years 2008 and 2009. The rand fluctuated significantly in these years and it can be deemed volatile. However, although the rand was relatively stable in 2010 , on a month to month basis, the rand was too volatile. In other words the rate with which it fluctuated from one month to the next was too much and this deems it volatile 


\subsection{An overview of the developments on the JSE}

The Johannesburg Stock Exchange is the oldest stock exchange market in Africa. Structural, regulatory and technological changes over the past decade have made the JSE to have many positive changes. Many positive developments have been noticed and as a result of this "the JSE is on the radar screen of many international investors today" (Oxford Business Group, 2008:59). Positive developments have been characterized by significant changes in the economic indicators mainly composed of, among other things, total volume and value of shares traded on the JSE. Figure 3 below shows the trends of the volume of shares traded on the JSE between 2000 to 2010.

Figure 3: JSE stock market transactions: Total volume of shares traded on the JSE

\section{Source: Data compiled from SARB, (2012)}

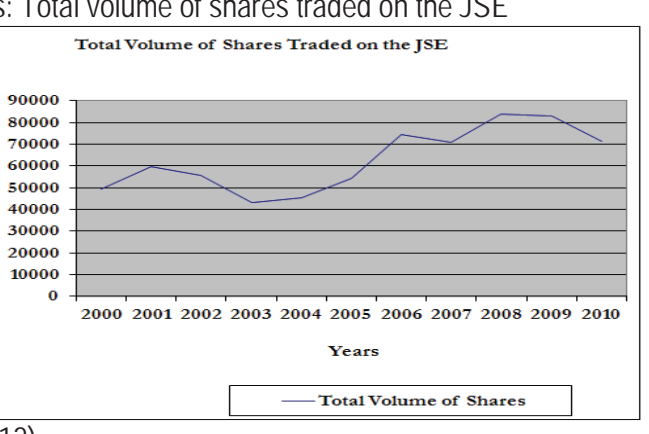

Figure 3 shows that the volume of shares rose in 2000 but fell sharply in 2001 and 2002 respectively. The volume of shares rose slightly in 2003 and trend continued till 2007. The volume of shares began to decline in the year 2008. Here, the global financial crisis played a huge role in the fall of the total value of shares traded on the JSE. The total value and volume of shares traded on the JSE has been developing from the year 2000 onward. Although they have been falling in some years, they speedily rose again in the following year and the increasing trend continued.

\section{Methodology}

Data for the study was obtained from the Johannesburg Stock Exchange and the South African Reserve Bank. The study used nominal figures and it employed monthly South African data for the period 2000 - 2010. The data frequency selected shall be monthly so as to ensure an adequate number of observations.

\subsection{Model specification}

In order to measure the impact of currency volatility on the stock market in South Africa, this study followed Subair's (2009) model. Subair (2009) used the GARCH model to investigate the impact of exchange rate volatility on the stock market performance in Nigeria. The explanatory variables that are included in this study's model are: the prime overdraft interest rate, total mining production, exports, and US interest rates. The model, therefore, takes the form:

$$
L S M C=\beta_{0}+\beta_{1} L R A N D V O L_{t}+\beta_{2} L T M P_{t}+\beta_{3} L I N T_{t}+\beta_{4} L M 3_{t}+\beta_{5} L U S I N T_{t}+\varepsilon_{t} \ldots
$$

Where LSMC is stock market capitalisation, RANDVOL is the volatility of the rand, TMP is total mining production, INT is interest rates, M3 is money supply and USINT is United States interest rates, $\varepsilon_{t}$ is a white noise error term and the $L$ in the above model stands for natural logs

\subsection{Data analysis}

Several tests such as descriptive statistics, $\mathrm{ARCH}$ test and unit root test were performed to examine the data characteristics. This was done to make sure that the estimation technique (GARCH) chosen is appropriate for the data.

\subsubsection{Descriptive statistics of monthly changes of stock market capitalisation and exchange rate.}

Descriptive statistics were performed to examine if the Randvol and $\mathrm{MC}$ exhibit time varying volatility and leptokurtosis 
characteristics. The two main variables of the study are examined because these variables determine the estimation technique for the study. The statistics of the Randvol and MC series are displayed in Table 1 below.

Table 1: Descriptive statistics

\begin{tabular}{|l|c|c|}
\hline \multicolumn{1}{|c|}{ Variable } & Randvol & MC \\
\hline Mean & 1.04 & 267176.3 \\
\hline Standard Deviation & 6.21 & 193372.5 \\
\hline Skewness & 8.2 & 4.26 \\
\hline Kurtosis & 69.63 & 28.2 \\
\hline J.B & 39.83 & 14.57 \\
p-value & 0.000 & 0.000684 \\
\hline
\end{tabular}

Statistics from Table 1 show that the J-B value of 39.83 deviated from normal distribution. Similarly, skewness and kurtosis represent the nature of departure from normality. The randvol value for skewness is 8.2 and it reflects positive skewness and the value for kurtosis is 69.63 and this suggests that there is peakedness in the randvol. From this it can be observed that the randvol variable exhibits significant deviations from normality. The coefficient of kurtosis is 69.63 and it is larger than three. This demonstrates significant lerptokurtosis. A distribution with a coefficient larger than 3 is said to be leptokurtic and one with a coefficient smaller than 3 is platykurtic. The MC variable reflects positive skewness with a value of 4.26 and this shows that there is asymmetry in the MC variable.

\subsubsection{Testing for $\mathrm{ARCH}$ effects}

Brooks (2008) argues that it is worthwhile first to compute the ARCH test to make sure that this class of models (GARCH) is appropriate for the data. In this regard, the ARCH test was used to test for ARCH effects on the residuals. The results are presented by table 2 below.

Table 2: ARCH test

\begin{tabular}{|l|}
\hline Heteroscedasticity Test: ARCH \\
\hline F-statistic 7.447 Prob.F $(5,121) 0.00000$ \\
\hline Obs*R-squared 29.885 Prob. Chi-Square(5) 0.00000 \\
\hline
\end{tabular}

Table 2 shows that the statistic labelled "Obs*R-squared" is the ARCH test of autocorrelation in the squared residuals. The $p$-value (0.0000) indicates that we can reject our null hypothesis of no heteroscedasticity in the residuals. In other words, the zero probability value strongly shows the presence of heteroscedasticity in the residuals.

\subsubsection{Testing for stationarity}

If the mean and variance are constant over time, then the series is stationary. Stationarity is essential for standard econometric theory. Two unit root tests were performed; the Augmented Dickey Fuller and the Phillip Perron test. Both of them showed that that all variables were not stationary in levels but became stationary after first differencing. The results from the Phillip Perron test are given in Table 3 below.

Table 3: Unit Root/ Stationarity Tests: Phillips Peron Test

\begin{tabular}{|c|c|c|c|c|}
\hline & \multicolumn{2}{|c|}{ Phillips Perron (Intercept) } & \multicolumn{2}{|c|}{ Phillips Perron (Trend and intercept) } \\
\hline Variables & Level & $1^{\text {st }}$ Difference & Level & 1stDifference \\
\hline $\begin{array}{c}\text { M3 } \\
\text { (P value) }\end{array}$ & $\begin{array}{c}1.194002 \\
0.9980\end{array}$ & $\begin{array}{c}-10.49386 \\
0.0000\end{array}$ & $\begin{array}{c}-2.122939 \\
0.5279\end{array}$ & $\begin{array}{c}-10.59217 \\
0.0000\end{array}$ \\
\hline $\begin{array}{c}M C \\
\text { (P value) }\end{array}$ & $\begin{array}{c}10.51483 \\
0.0000\end{array}$ & & $\begin{array}{c}-11.11609 \\
0.0000\end{array}$ & \\
\hline $\begin{array}{c}\text { POR } \\
\text { (P value) }\end{array}$ & $\begin{array}{c}1.417308 \\
0.5720\end{array}$ & $\begin{array}{c}-10.72564 \\
0.0000\end{array}$ & $\begin{array}{c}1.898069 \\
0.6499\end{array}$ & $\begin{array}{c}-10.73697 \\
0.0000\end{array}$ \\
\hline $\begin{array}{l}\text { RANDVOL } \\
\text { ( } p \text { value) }\end{array}$ & $\begin{array}{c}-2.143811 \\
0.2281\end{array}$ & $\begin{array}{c}-8.037357 \\
0.0000\end{array}$ & $\begin{array}{c}-2.245581 \\
0.4602\end{array}$ & $\begin{array}{c}-8.046197 \\
0.0000\end{array}$ \\
\hline $\begin{array}{c}\text { TMP } \\
\text { (P value) }\end{array}$ & $\begin{array}{c}4.730044 \\
0.0000\end{array}$ & & $\begin{array}{c}-4.708536 \\
0.0000\end{array}$ & \\
\hline USINT & 1.357667 & -4.581038 & -1.467586 & 4.527591 \\
\hline
\end{tabular}




\begin{tabular}{|c|c|c|c|c|c|}
\hline \multicolumn{2}{|c|}{ (P value) } & 0.6011 & 0.0002 & 0.8358 & 0.0020 \\
\hline Critical & $1 \%$ & 3.480818 & 3.480818 & 4.029595 & 3.481217 \\
\cline { 2 - 6 } Values & $5 \%$ & 2.883579 & 2.883553 & -3.444487 & 2.883753 \\
\hline \multicolumn{2}{|c|}{ ** and * denotes rejection of the null hypothesis at 1\% and 5\% respectively } \\
\hline
\end{tabular}

Table 3 shows that all variables were not stationary in levels. At levels, the $p$ - values of the variables all being greater than 0.05 indicate that we could not reject the null hypothesis of the existence of unit root in levels for all variables. However, the variables are stationary are stationary after first differencing them. The magnitude of the $p$-values (less than 0.05 ) are significant, indicating that the variables are stationary at first difference.

\subsection{Presentation and Interpretation of results}

The hypothesis of interest is the extent to which changes in the conditional mean of the variables are associated with changes in the MC. Table 4 presents the results from the estimated normal GARCH (1.1) model.

Table 4: Results from the GARCH (1.1) model

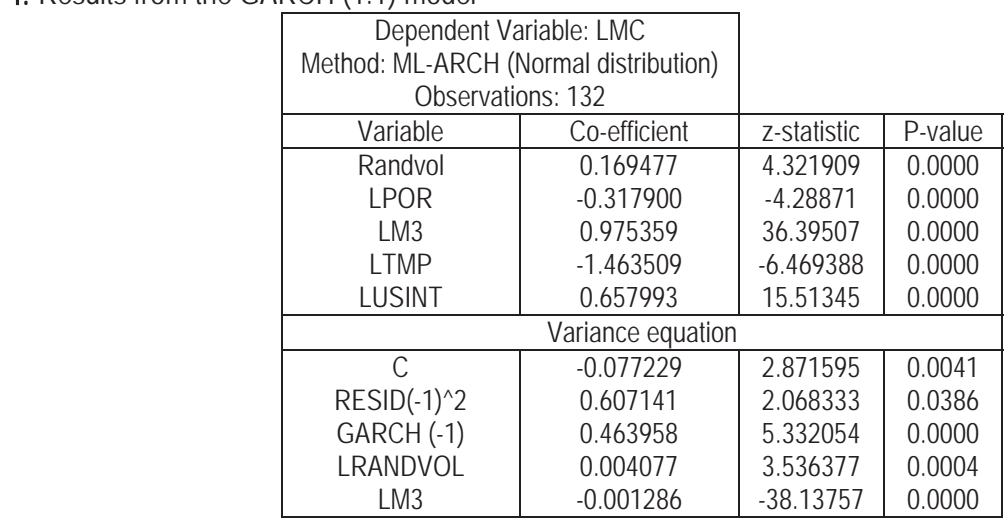

R-Squared 0.623359 , Adjusted R-Squared $\quad 0.608413$

\subsubsection{Mean equation}

The sign of the interest rates is negative; a one percentage point increase of interest rates (POR) decreases market capitalisation (MC) by 0.32 percentage points. Results indicated that there is a negative relationship between interest rates and market capitalisation. has been observed by several studies such as those of Adjasi and Biekpe (2005) and Büyükşalvarcı (2010).

The coefficient of TMP is negative and statistically significant indicating that increases in TMP dampens stock market activities. In other words, an increase in TMP volatility will lead to a fall in market capitalisation. Mayowa (2011) in his analysis of the long run co-movements between financial system development and mining production in South Africa also came with a similar result. The coefficient of $\mathrm{M} 3$ is positive and statistically significant indicating that increases in money supply increases stock market activities. Increase in money supply leads to increase in liquidity that ultimately results in upward movement of nominal equity prices. Li (2012) found a similar result in a study that investigated the relationship between money supply and stock market in Europe.

A one percentage point increase of US interest rates (USINT) increase market capitalisation by 0.65 percentage points. The value of the US interest rates is positive; meaning that an increase in US interest rates will lead to a rise in market capitalisation. The US interest rates sign was expected to be negative but results have shown the positive. It is expected that, when US interest rates rise, there would be a shift of investment from economies with low interest rates towards those with high interest rates (US).

\subsubsection{Variance equation}

The variance equation represents the GARCH model and it is in this equation that the volatility of the rand volatility and 
M3 were captured. The interpretation is as follows;

Results showed that a one percentage point increase of rand volatility increases market capitalisation by 0.004 percentage points. This shows that currency volatility has a very weak but positive impact on stock market activities. An increase in currency volatility will cause a very small increase in market capitalisation. The outcome of a positive sign of the rand volatility goes hand in hand with results from other studies that investigated the relationship between these two variables. The result of this study goes hand in hand with that of Karoui (2006) and that of Adjasi and Biekpe (2005).

The coefficient of M3 is negative and statistically significant indicating that fluctuations in money supply decreases stock market activities. A one percentage point increase of money supply (M3) decreases market capitalisation by 0.001 percentage points. This result is consistent with the findings of Flannery and Protopapadakis (2002).

\subsection{Diagnostic Tests}

Gujarati (2004:516) argues that diagnostic tests should be performed so that the model finally chosen is a good model in the sense that all the estimated coefficients have the right signs, they are statistically significant on the basis of the $t$ and $F$ tests. In this regard, this study employs the Histogram and Normality test, Correlogram of Squared Residual Test, and the Heteroscedasticity² test as its diagnostic tests.

\subsubsection{Normality test}

Normality test was conducted to test the residuals' normality. Economic theory expects the residuals to be normally distributed. Table 5 presents the Normality test.

Table 5: Normality Test

\begin{tabular}{|l|}
\hline $\begin{array}{l}\text { OLS Normal GARCH GARCH } \\
\text { (student t distribution) }\end{array}$ \\
\hline Skewness 5.891 .36 .87 \\
\hline Kurtosis 43.677 7.42 54.68 \\
\hline J.B 986390.781573 \\
(Probability) 0.0000 .0000 .000 \\
\hline
\end{tabular}

Results from the Normality test show that the normal GARCH model best reduced the problems of fat tails and volatility clustering. The kurtosis and skewness are smaller under the normal GARCH model (7.42 and 1.3 respectively). In this regard, it can be concluded that the residuals are not normally distributed. However, it must be noted that the residuals have been drawn towards normality. The non-normality of residuals in volatile time series data has been observed in various studies. Arouri, Jaqdi, and Nguyen (2010) also came up with a similar result in a research on "the dynamics of emerging stock markets".

\subsubsection{Heteroscedasticity test}

The ARCH test was conducted to check the presence of heteroscedasticity in the residuals. Table 6 shows the ARCH test after using the GARCH model.

Table 6: ARCH test

\begin{tabular}{|l|}
\hline Heteroscedasticity Test: ARCH \\
\hline F-statistic 0.187667 Prob.F $(5,121) 0.6656$ \\
\hline Obs*R-squared 0.190300 Prob. Chi-Square(5) 0.6627 \\
\hline
\end{tabular}

Table 6 presents results for the ARCH test. Engle's LM test indicates that there are no more ARCH effects. The $p$ value of the Obs*R-squared in not significant; it is greater than 0.05 and this indicates that there is no ARCH present. The pvalue is 0.6627 and this shows that there is no heteroscedasticity in the residual.

\subsubsection{Testing for autocorrelation: Q-statistic Test}

${ }^{2}$ This is important to see if the normal GARCH model has eliminated heteroscedasticity well. 
The Q-statistic test was carried out and results showed that the Q-statistics were all significant at all lags under the normal GARCH model, indicating that there is no significant serial correlation in the residuals. Table 7 presents results from the Q-statistic Test.

Table 7: Correlogram squared residuals

\begin{tabular}{|lllll|}
\hline & AC & PAC & Q-Stat & Prob \\
\hline 1 & -0.038 & -0.038 & 0.1960 & 0.658 \\
2 & -0.066 & -0.068 & 0.7904 & 0.674 \\
3 & -0.017 & -0.023 & 0.8323 & 0.842 \\
4 & 0.265 & 0.260 & 10.506 & 0.033 \\
5 & -0.022 & -0.005 & 10.575 & 0.060 \\
6 & -0.011 & 0.020 & 10.592 & 0.102 \\
7 & -0.047 & -0.043 & 10.898 & 0.143 \\
8 & -0.083 & -0.168 & 11.887 & 0.156 \\
9 & -0.025 & -0.035 & 11.974 & 0.215 \\
10 & 0.030 & 0.013 & 12.106 & 0.278 \\
11 & -0.036 & -0.014 & 12.292 & 0.342 \\
12 & -0.037 & 0.035 & 12.497 & 0.407 \\
13 & -0.005 & 0.006 & 12.500 & 0.487 \\
14 & 0.049 & 0.035 & 12.858 & 0.538 \\
15 & -0.033 & -0.029 & 13.018 & 0.601 \\
16 & -0.016 & -0.034 & 13.058 & 0.669 \\
17 & -0.021 & -0.034 & 13.126 & 0.728 \\
18 & -0.032 & -0.065 & 13.286 & 0.774 \\
19 & -0.020 & -0.016 & 13.349 & 0.820 \\
20 & -0.018 & -0.017 & 13.399 & 0.860 \\
\hline
\end{tabular}

From table 7 it can be observed that all p-values are above 0.05 and as a result of this the null hypothesis of no serial correlation is not rejected. This shows that there is no correlation in the residuals. This shows that the mean equation was correctly specified. Uh (2005) held that if the mean equation (conditional variance equation) is correctly specified, all Q-statistics of standardised residuals should be insignificant with no observable autocorrelation.

\section{Conclusion and Recommendations}

The main objective driving this study has been to examine the impact of currency volatility on the stock market in South Africa. The analysis of this study reported a very weak relationship between exchange rate volatility and the stock market. This result is not supportive of the presumption that the uncertainty surrounding exchange rate market distorts efficient investment allocation. However, the stock market was seen to be affected by other macroeconomic variables namely: interest rates, total mining production, money supply and the United States interest rates. Interest rates were seen to have a negative impact on the stock market. This is supported both by economic theory and a number of studies.

The findings from this study have a number of policy implications. Firstly, the weak volatility transmission from the rand to stock market may be indicative of increased use of hedging instruments by firms on the JSE. More hedging instruments needs to be put in place to ensure the elimination of negative effects of rand volatility. These hedging instruments should be efficient and they should not distort the normal functioning of the JSE. Secondly, since the South African stock market is not really exposed to the negative effects of currency volatility. Relevant policy-makers in government can use exchange rate as a policy tool to attract foreign portfolio investment. Thirdly, the JSE needs to maintain its co-operation with world class stock markets such as the LSE. This might be one of the reasons the JSE is able to cushion negative effects of currency volatility. Macroeconomic spillovers from developed countries are usually hard to deal with but if there is some integration between the JSE and developed countries, news about any possible developments in these markets will reach the JSE fast and measures to deal with any possible effects of these macroeconomic developments will be put in place way before the markets are affected.

\section{References}

Adjasi, C. K.D., \& Biekpe, B.N, (2005). Stock Market Returns and Exchange Rate Dynamics in Selected African Countries: A bivariate analysis. [Online]. Available at: www.ajbms.org/articlepdf/2ajbms20121120721.pdf (May 17, 2011)

Alam, M., Uddin, G.S \& Taufique, R.K. (2007), The Relationships between Exchange Rates and Stock Prices: Empirical Investigation from 
Johannesburg Stock Exchange. [Online] Available at: http://www.academia.edu/822774/The_Relationships_between Exchange_Rates_and_Stock_Prices_Empirical_Investigation_from_Johannesburg_Stock_Exchange (August 6, 2011)

Arouri, M.E.H., \& Jawadi, D.K. (2010). The Dynamics of Ëmerging Stock Markets: Empirical Assessments and Implications. London: Springer

Benita, G., \& and Lauterbach, B. (2004). Policy Factors and Exchange Rate Volatility: Panel Data Verses a Specific Country Analysis. Jerusalem, Research Unit; Foreign Exchange Activity Department, Bank of Israel

Bollerslev, T. (1986). Generalized autoregressive conditional heteroscedasticity. Journal of Econometrics, 31, 307-327

Brooks, C. (2008). Introductory economics for finance. U.K: Cambridge University Press

Büyükşalvarcı, A. (2010), The Effects of Macroeconomics Variables on Stock Returns: Evidence from Turkey. [Online] Available at: http://www.eurojournals.com/ejss_14_3_06.pdf (February 3, 2012)

Engle, R.F. (1982), Autoregressive Conditional Heteroscedasticity with Estimates of the Variance of United Kingdom Inflation. [Online] Available at: http://econpapers.repec.org/article/ecmemetrp/v_3a50_3ay_3a1982_3ai_3a4_3ap_3a987-1007.htm (July 17, 2011)

Flannery, M. J., \& Protopapadakis, A.A. (2002). Macroeconomic Factors do Influence Aggregate Stock Returns. Review of Financial Studies, 15, 751-782.

Gujarati, D. (2004). Basic Econometrics. India: McGraw-Hill Education

Hale, D., \& Hale, L.H. (2011). What's Next?: Unconventional Wisdom on the Future of the World Economy. U.K: Yale University Press

Iqbal, J., \& Haider, A. (2005). Arbitrage Pricing Theory: Evidence from an Emerging Stock Market. The Lahore Journal of Economics, 10,123-139

Joseph, N. (2002). Modelling the impacts of interest rate and exchange rate changes on UK Stock Returns. Derivatives Use, Trading and Regulation, 7,306-323.

JSE. (2011), Market Profile: March 2011. [Online] Available at: http://www.jse.co.za/Libraries/JSE_-_Products_Services_-_Statistics__Equity_Market_Profiles/20110301-Market_Profile_pdf.sflb.ashx (March 8, 2012)

Karoui, $\bar{A}$. (2006), The correlation between FX rate volatility and stock exchange returns volatility: An emerging markets overview. [Online] Available at: http://www9.georgetown.edu/faculty/evansm1/New\%20Micro/Karoui.pdf (May 19, 2012)

Li, Y. (2012), Empirical study on the relationship between money supply and stock market in Europe. [Online] Available at: http://dl.acm.org/citation.cfm?id=2403722 (May 1, 2012]

Mail and Guardian. (2011), SA volatility hurting the rand. [Online] Available at: http://mg.co.za/article/2011-11-13-sa-volatility-hurting-the-rand (November 13, 2011).

Mayowa, S.A. (2011), An analysis of the long run co-movements between financial system development and mining production in South Africa. [Online] Available at: http://eprints.ru.ac.za/2541 (November 12, 2011)

Mishkin, F. S (2001). The Economics of Money, Banking and Financial Markets. New York: Addison Wesley

Morales, L. (2008), Volatility Spillovers between Equity and Currency Markets: Evidence from Major Latin American Countries. [Online] Available at: http://www.scielo.cl/pdf/cecon/v45n132/art02.pdf (May 13, 2012)

Muchaonyerwa , F. (2011). Business Cycles and Stock Market Performance in South Africa. Masters in Commerce. Alice: University of Fort Hare

Muhammad, N., \& Rasheed, A. (2011), Stock Prices and Exchange Rates: Are they Related? Evidence from South Asian Countries. [Online] Available at:http://www.pide.org.pk/pdf/psde\%2018AGM/Stock\%20Prices\%20and\%20Exchange\%20Rates.pdf (May 13, 2012)

Nedbank. (2012), Economic Forecasts. [Online] Available at: http://www.nedbankgroup.co.za/economicForecasts.asp (September 7, 2012)

OECD. (2010). OECD Economic Surveys: South Africa 2010. France, OECD Publishing

Ogunleye, K.E. (2002, Exchange Rate Volatility and Foreign Direct Investment in Sub-Saharan Africa: Evidence from Nigeria and South Africa. [Online] Available at: http://www.csae.ox.ac.uk/conferences/2009-EDiA/papers/196-Ogunleye.pdf (September 15, 2011)

Olugbenga, A.A. (2012), Exchange Rate Volatility and Stock Market Behaviour: The Nigerian Experience. [Online] Available at: www.iiste.org/Journals/index.php/RJFA/article/download/../1469 (May 3, 2012)

Omojimite, B.U., \& Akpokodje, G. (2010). A Comparative Analysis of the Effect of Exchange Rate Volatility on Exports in the CFA and Non-CFA Countries of Africa. Kamla-Raj J, 24, 23-31.

Oxford Business Group. (2008). The Report: South Africa 2008. UK: Oxford Business Group

Pilbeam, K. (1998). International Finance. (2nd ed). UK: Basingstoke; Mac

Pilinkus, D., \& Boguslauskas, V. (2009), The Short-Run Relationship between Stock Market Prices and Macroeconomic Variables in Lithuania: An Application of the Impulse Response Function. [Online] Available at: http://internet.ktu.lt/t/mokslas/zurnalai/inzeko /65/1392-27582009-5-65-026.pdf (October 15, 2011)

Pretorius, A., \& de Beer, J. (2002), Can some of South Africa's Recent Exchange Rate Volatility be Attributed to Contagion? TIPS Forum 2002: Global Integration; Sustainable Development And The Southern African Economy. [Online] Available at: http://www.tips.org.za/node/230 (October 15, 2011).

Raputsoane, L. (2008), Exchange rate volatility spillovers and the South African currency. [Online] Available at: http://www.tips.org.za /files/Leroi_Exchange_rate_volatility_spillovers-24_Oct_2008.pdf (July 17, 2011).

Rashid, A., \& Karachi, I. (2007), Exchange rates or stock prices, what causes what: A firm level empirical investigation?. [Online] Available at: http://mpra.ub.uni-muenchen.de/27209/1/MPRA_paper_27209.pdf (July 17, 2011).

Sekmen, F. (2011), Exchange rate volatility and stock returns for the U.S. [Online] Available at: http://www.academicjournals.org lajbm/pdf/pdf2011/30Sept/Sekmen.pdf (April 2, 2012)

Stern, J.M., \& Chew, D. (2003). The Revolution in Corporate Finance. USA: John Wiley \& Sons,

Subair, K. (2010), Exchange Rate Volatility and the Stock Market: The Nigerian Experience. [Online] Available at: www.aabri.com /OC2010Manuscripts/OC10113.pdf (September 2011).

Uh, R.S. (2006). Financial Institutions and Services. New York: Nova Science Publishers

United Nations. Economic Commission for Africa. (2008). Assessing regional integration in Africa III. Addis Ababa, Africa Union 